\title{
Historical Timber-Framed Buildings: Typology and Knowledge
}

\author{
Maria Eunice da Costa Salavessa \\ Engineering Department, Centro de Estudos, Transdisciplinares para o Desenvolvimento, University of Trás-os-Montes and Alto \\ Douro, Portugal
}

\begin{abstract}
This paperprovides a historical overview intending to clarify the methods of interpretation of timber-framed buildings by different authors of construction treatises, and structural intentions of the carpentry designers and master builders, throughout the centuries, until the period when it became scientific structural theory. It describes the "box-frame" construction that appeared in Lisbon, after the earthquake of 1755 , characterized by its good seismic resistance. This knowledge is important to determine a strategy of an efficient restoration practice in historical constructions which require an intervention subordinated to its raised patrimonial and artistic value, minimum, which respects the authenticity of its structural and construction conception and which is reversible and compatible, in physical, chemical, mechanic and aesthetic terms. Empirical understanding of the most important properties of wood to structure purposes, the defects of structural timbers, the framing and the preliminary survey followed by the structural survey were some of the difficulties which can be overcame in practice.
\end{abstract}

Key words: Structural timbers, survey of traditional timber-frame buildings knowledge.

\section{Introduction}

The wood played an important role in the civil construction, for being a renewable constructive material which adapts, in harmonious way, to different structural and architectural solutions. The study of the civil carpentry is an interdisciplinary subject, which appeals the knowledge of construction history and technology, surveying technologies, technology of the wood and structural engineering. The geometry, the hierarchy of the components of the "skeleton", connected by wooden-pegged joints, give the stability and strength to the traditional buildings of timber with rough stone and to the historic large timber complexes. Empirical understanding of the capabilities of timber and its proper cutting was an important knowledge to building with a material having variable properties. Only certain species grown under specific conditions

Corresponding author: Maria Eunice da Costa Salavessa, $\mathrm{PhD}$, assistant professor, research fields: conservation of architectural heritage, eco-construction. E-mail: eunicesalavessa@sapo.pt. survived over time for mayor construction, and for that very reason treatises constitute important source of technical information for the historic structures.

Timber and timber structures, have complicate deformational behavior because of the flexibility of the wood, the nature of the tissues and the general direction of the grain, which turns difficult the assess of the cause of the stress responsible for the deformations. The knowledge of failures of timber structures and of deformation and breaking processes of timber members, become, since the past, the general analytic method for understand their behavior and causes of failure. This knowledge was the base to the design and dimensioning of the new structures, in the past, and a method found for the conservation of the timber structure. The methods for preserving timber buildings must be compatible with the species of wood used in them, which rate of decay of the wood is different from one region to another. Traditional methods of repair presuppose knowledge of traditional design methods and construction techniques. 


\section{Vitruvius and the Classical Antiquity Construction}

\subsection{Theophrastus and Vituvius}

Woodland resources were differently distributed, accordingly to the geography and climate. It is possible distinguishing extensive forests of pine and conifers prevailed in the Mediterranean basin from that of Northern Europe, and oak suitable for construction predominated in the north of the Alps and in the British Isles. In the ancient Mediterranean region the mountain fir, Aleppo pine, oak, cedars and cypress of Lebanon and Crete were trees suitable for construction and shipbuilding. Theophrastus (370-ca. 285 B.C.), wrote an extensive botanical treatise, Inquiry into Plants, which includes, in Book Five, considerable practical information gleaned from ancient carpenters and woodsmen. He observed that trees of north-facing slopes produce bigger, more erect, straighter grains and tougher timber. The hardest woods of several species of oak were wet before bore holes on them, for the use of dowels or pegs for connections of posts and beams. Glue would have been used for major structural joining without the addition of pegs or nails, especially in ceiling construction [1].

Vitruvius (25 D.C.), in his treatise of architecture, glorify the nobility of oak-wood, the most appropriated wood for construction, owing to its hardness and toughness. He refers, yet, to other woods for construction like silver and black poplar (at pile-work), willow, lime-tree, agnus castus, elm, carpel, cypress, pine, cedar and larch; the latter ones having the particularity of be not attacked by insects or rottenness and the larch resist fire and not float on the water [2].

\subsection{The Roman construction}

The Romans, from the republican period, had intensified the construction planning, through its industrialization. The opus craticium, the half-timbered wall, was the wide spreader mixed structure in the ancient architecture of the Italic
Peninsula and of Europe, but very few evidences of it were left, owing the perishable nature of the materials which constitute the structure. The only Roman exemplars which persisted over time were those ones of Pompeia and Herculanum. The vernacular patterns are constituted by a socle of masonry, where a structural timber-framingrests on, composed of vertical posts and studs, diagonal braces and horizontal beams and plates timbres and the spaces in between, the panels, were filled with timber or daub. In Pompeia and Herculanum, multi-storiedbuildings have, on the ground-floor, a $0.40 \mathrm{~m}$ to $0.50 \mathrm{~m}$ thickness walls, of masonry or ashlar masonry and, the upper levels walls, of 0.20 maximum thickness, are timber-framing panels whose spaces in between are infilled with the opus incertum masonry, with the stones bonded by a mortar; the internal partition walls are of the same constitution. Sometimes, timber-framed balconies are projected above the street, supported by diagonal braces or vertical posts [3].

Ancient authors including Julius Caesar, Strabo and the Elder Pliny give a good indication of spans exceeding 25 meters, as Roman timber structures and bridges. The scenes on the Column of Trajan, record the Dacian campaigns of the early 2nd century A.D., and shows the Roman army on the Danube frontier, occupied with hewing oak and building fortifications with trussed timber towers and rampart walls. Is extraordinary, the quality and monumentally of Roman timberwork, including shipbuilding, machinery, and military devices. They built towered log forts in the provincial limes, enormous granaries, bridges across the Rhine and Danube, and numerous wide-spans, open-roofed public halls.The trussed Danube Bridge, in the actual Romania, of Trajan's engineer-architect, Apollodorus of Damascus, was a great building achievement of the emperor. It was constructed of twenty masonry piers each 70 Roman feet apart, 150 feet high, and 60 feet wide. From pier to pier were trussed segmental arches sprung from a triangulated support. This array of arches formed the support for the 
joists of the deck. The deck was flanked by timber railings. The radial timbers represent clasps to secure the jointed timbers of the arch. The system acts, essentially in compression. Unfortunately, this magnificent structure was demolished by the Emperor Hadrian (Fig. 1a) [1].

The triangle or the combination of triangles in a timber truss, cannot be altered without changing the length of its sides, cannot be distorted, so that, a truss is not dependent on rigid joints stability. Member stresses are lower than in a beam because the major forces in truss members are direct tension or compression rather than bending. The ancient builders employed the principle of the truss, tying the feet of the rafters, creating a system of triangulation, to use timbers of lesser length and especially of smaller cross-section to introduce wide spans.In this manner the rafter feet do not spread outward, and the horizontal, overturning force at the wall head was restrained. This technological development permit creating larger spans above less massive walls, and opening up the top of the wall without disturbing stability, allowing light to enter the building interior at a high level, as in the Roman basilicas of Old St. Peter's, and St. Paul's Outside the Walls (Fig. 1c).

The Roman basilica was essentially a long peristyle hall, have an aisled structure based on a wide central nave taller than the aisles, and as Vitruvius referred, its internal span was three to four times greater than flanking aisles (Book V. I.4). The supporting walls of the nave incorporated the clerestory windows or it was lit by windows in galleries in the second story over the side aisles (Fig. 1b). For nave spans from about 13 to 30 meters, the triangulated tie-beam truss placed at equal intervals offered an ideal technological solution. At St. Paul's Outside the Walls, for long spans, paired trusses incorporating hanging members clasped by double fir ties provided support for the tie beam
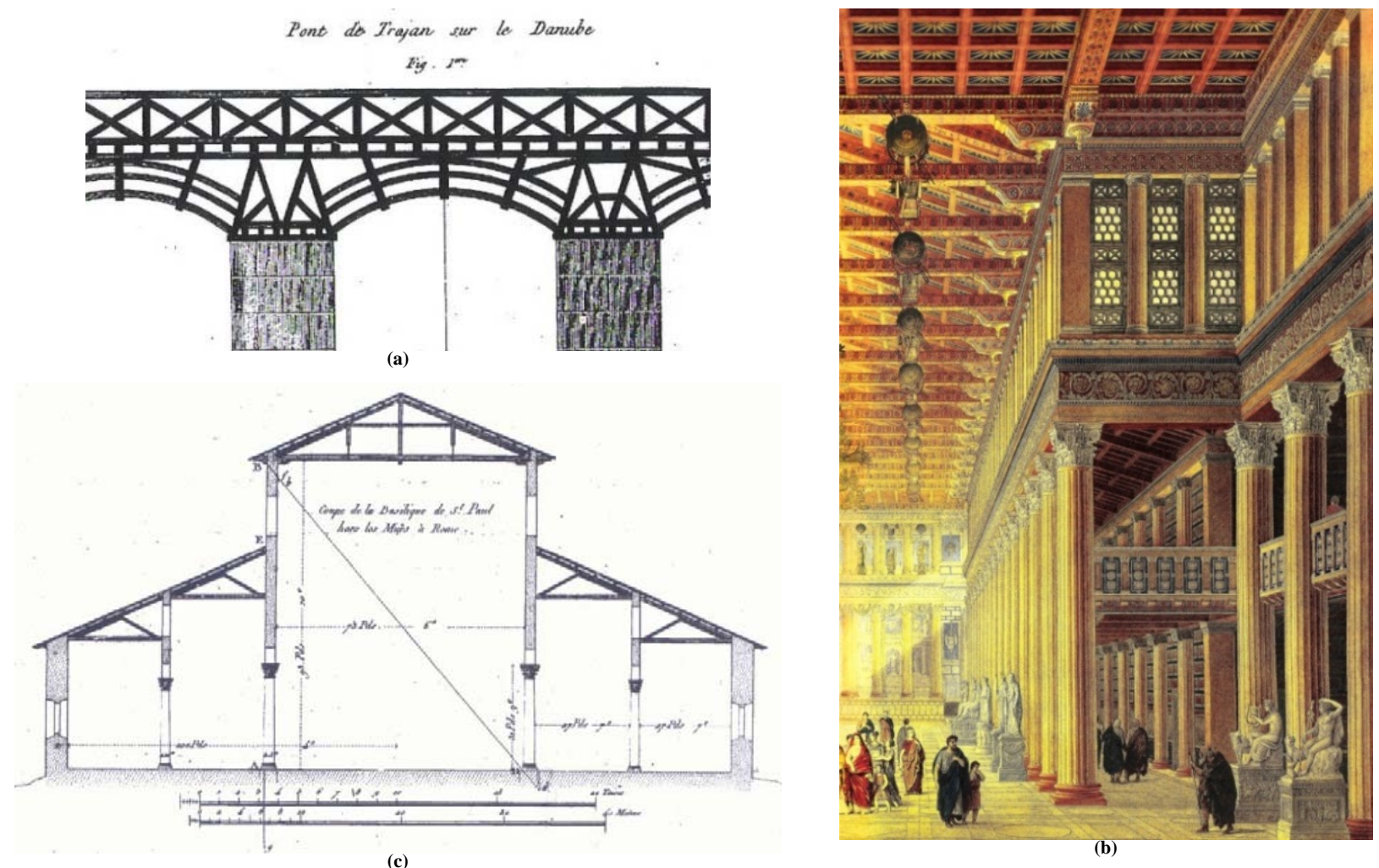

Fig. 1 (a) Trajan's Bridge across the Danube [4]; (b) Aquarelle of interior of an ancient basilica constituted anew (J.I. Hittorff, 1831, d'Orsay Museum); (c) Section of Basilica of St. Paul's Outside the Walls timber-framing, before the fire of 1823 [4]. 
along its length, and these doubled trusses carry the roof's superstructure through purlins. The basilica of St. Paul's Outside the Walls, in Rome, whose roof framing spanned 24.30 m, was recorded by Rondelet (Fig. 1c) before its destruction in the disastrous fire of 1823 , where were discerned three different truss systems of different dates. For the earliest truss, repaired in A.D. 816, constructed of pine, was devised a double-framed system using paired tie beams and a central hanger as a clasp, secured by the apex by an iron bolt through the joint of the rafters [4]. To prevent the tie beam from sagging the base is fastened together by a threaded wooden dowel. The compound trusses support a series of purlins and a ridge piece of the roof. The trusses are spaced at bay intervals of about $3.5 \mathrm{~m}$, and the rafters within these frames are spaced apart at only $20 \mathrm{~cm}$. The doubled truss at St. Paul's had well-developed tension joints necessary for the function of the central hung post that supports the midpoint of the long tie beams [1].

\section{Construction of Middle Age}

\subsection{The "Cruck" and the "Stabbau"}

The cruck frame has been used from 1st century, in Great-Britain, Germany and Netherlands. It conciliates the timber members of the façade structure with the trusses for roof. Inclined timbers, like principal rafters of a roof truss, rest directly on the ground or are inserted in it and are joined in pairs at their apex. Those pairs of cruck blades are spaced at equal intervals along the building and have not a ridge-pole, but a ridge purlin which is a longitudinal member that receive the upper ends of common rafters at the apex of the roof. The cruck truss can be exposed in the gable, framing a composition of wall posts, studs, tie beams, rails, wall plates, collars, rafters, braces and window-frames. The enclosing walls, in the early cruck-framed buildings were of earth or turf. Timber members of the wall can be exposed or concealed [5]. The cruck blades can be straight, bent or curved and the pairs of blades can take the shape of ogives. The latter ones correspond to oaks grown locally at windswept sites. They represent the whole stem below the height of its major branching. The cruck frame, developed in the later Middle Age, wide-span multi-storied construction. A cruck blade has in the section, the outer fibers in great tension [6].

The early medieval timber-framing, which evidences still rest in France, Germany and Netherlands, are constituted by two kinds of palisade, one with all vertical members, juxtaposed but not joined together, and the other one with corner and bay posts. The palisade-wall developed to the stabbau, with vertical timber members assembled through grooves and loose tongues. The stabbau was used in Scandinavian churches, and urban and rural buildings (Sweden and Denmark) in 10th and 11th centuries. The posts supported the roof timber frame, made with round logs of wood [5].

\subsection{Gothic Structures}

The twelfth century oak tie-beams of the roof of Notre Dame in Paris (Fig. 2a), are over $14 \mathrm{~m}$ in length and $24 \times 25 \mathrm{~cm}$ in section. After ca. 1300, till 16th century curved or elbowed oaks were used in arched multitier roofs. Metallic-edged blades, used widely in the middle ages, contribute to the technical development of hardwood carpentry and of complex joining [1].

The medievalhalf-timbered wall is a timber-framed wall constituted by plates, posts, studs, rails and reinforcement braces, raised on the building façades and in its interior, as partition walls. The voids between the studs or posts and rails or plates could be filled with wattle and daub or with stone and mortar covered with plaster, where were executed stuccos or molded fanciful decoration. The exposed timber members could be painted with contrastable colors like the yellow and black, the white and brown or the red and black. The construction of those half-timbered walls permitted the jetty construction, with upper floors supported by jetted joists and brackets, projected over the street, getting more space inside the buildings (Figs. 2 and 3). 


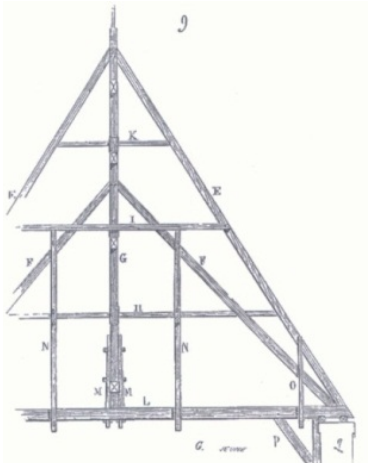

(a)

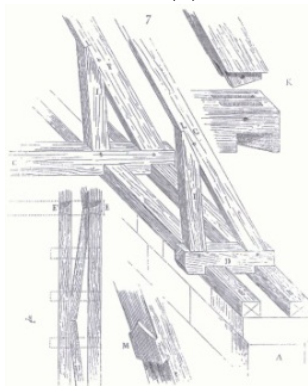

(b)

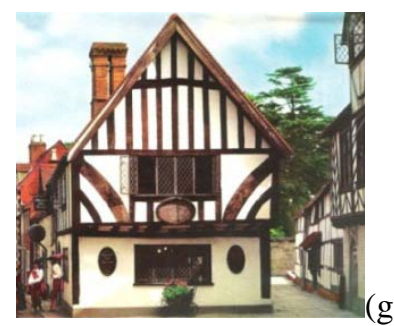

(g)
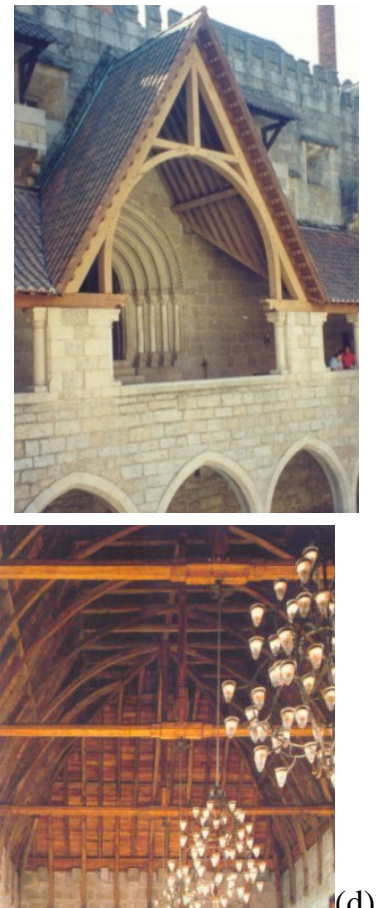

(e)

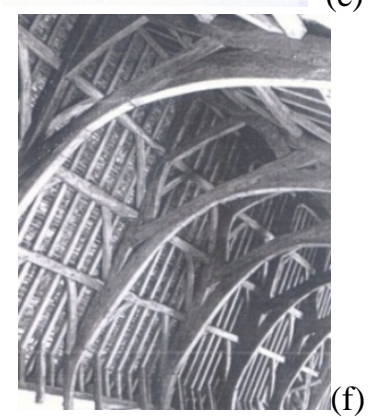

Fig. 2 (a) Notre Dame, Paris; (b) mortice, lapped, dovetailed joint; (c) four-way bracing, Amiens, 13th c. (Viollet-le-Duc); (d) Structural timber-framing roof, Duke’s Palace, Guimarães, 1999; (e) Westminster Hall, London, 1397(le-Duc); (f) Base cruck truss, tithe barn, Avon. (g) Okens House, Warwick, 1999.

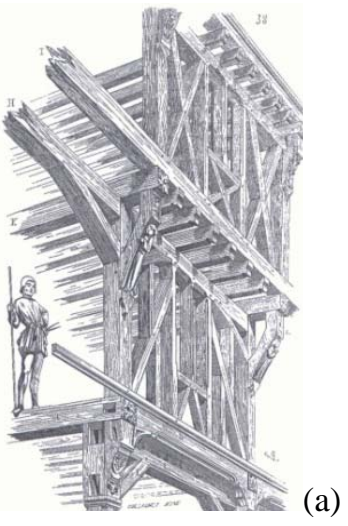

(a)

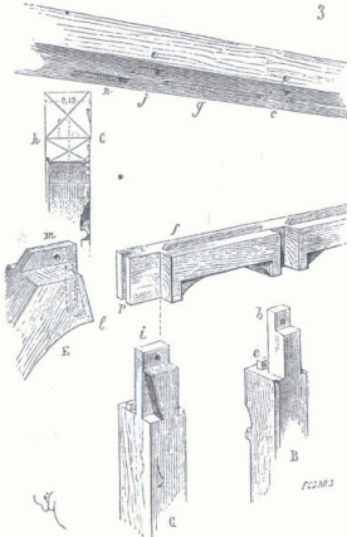

(b)

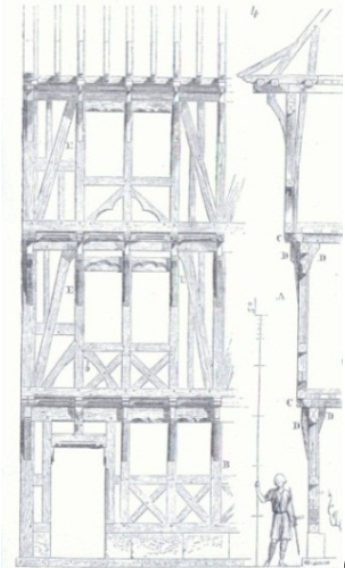

(c)
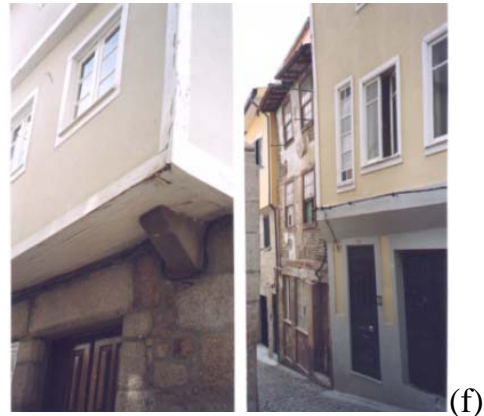

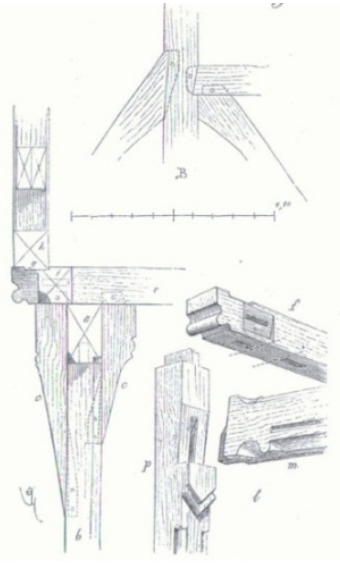

(d)

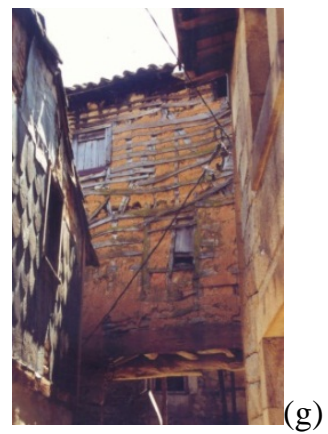

(g)

Fig. 3 (a) Timber-framing; (b) Joining, House of Dreux; (c) Timber-framed wall, House of Chateaudun; (d) Connections between posts, beams, studs, rails, and Sto. André braces; (Viollet-le-Duc); (e) Squareof Santiago, Guimarães, 1999; (f) Lamego, 2003; (g) Medieval Jesuit quarter, in Salzedas, 1999. 
The box-frame construction, where the timber members of the wall can be exposed or concealed, is usual in half-timbered buildings of Great Britain, especially in the Eastern Wales, south of Lancashire, Cheshire and west of Midlands. The spaces in between are filled with wattle and daub or brick, and the builders heighten the decorative effect, playing the patterns of the dark timber members with the white plastered panels (Fig. 2g). In other buildings, the timber-framed walls, both the timber members and the panels are concealed by a cladding of plaster, plain tiles, brick tiles or weather-board [7].

The Normans were excellent carpenters who used great length and curved timber members, adapted from the naval carpentry practice. They created joints which resisted very well the impact and vibrations and which did not stiffening iron pieces. The half-lapped and the halved joints had been used, already, in Middle Age and the timber members joined to the wall-plate, bressummer plate and sill-beam by mortice and tenon joints (Fig. 2b and Fig. 3b). Rarely the posts were placed in the corners of the building, being the framed wall arrested between two masonry walls which were the party-walls or the gables.

Viollet-le-Duc describes some French and medieval urban houses, from which still rest evidences. A three-storeyed house of Chateaudun, at the close of the 13th century, is an authentic timber skeleton, rested on a masonry socle of $1.5 \mathrm{~m}$ height (Fig. 3cd). The façades and the party walls are timber-framed walls, composed of plates, posts, braces and close-spaced studs. The two floors above are projected in suspense, supported by anchor-beams, jetted joists and brackets [8].

In the Spanish "Galician way" timber-framed wall, similar to the "enchamel",denominated "French", in Portugal, common in the region of Beira, laths of one face are fixed in alternation with the laths of the opposed face. While it is filling up with pebbles and mortaroccurred, to its containment, boards were fastened with nails to the laths and, then, were removed.In Portugal, this sort of house, where two or three-storeyed structural timber-framing is supported by masonry walls of the ground-floor, is common in several medieval villages, namely in the Norte of the country, like Porto, Braga, Guimarães, Chaves, Vila Real andBraganza (Fig. 3e, 3f, and 3g).

\section{De L'Orm, Palladio and the Renaissance Construction}

\subsection{Treatises from Renaissance}

Philipert de l' Orme, in his treatise of carpentry, of two volumes, published in 1561, Nouvelles Inventions pour Bien Bastir et a Petits Fraiz, idealized arched spans of 60 meters and large vaults of ogee profile. He proposed new structures, not based on traditional timber framing with triangulated beam members, but with segmental arches built up from small timber elements. He describes the vault with edges of plastered lathwork. The lathwork was fixed in a structure of wood composed with double wooden staves tied with wooden pegs, forming one curvature which is tied itself to a covering structure of ogee arcs with the same constructive system [9] (Fig. 4b and 4c).

De l'Ormexplains the way of bring together pieces of timber to make a built-up beam, and what specie of wood must be made the timber arch, illustrated in Fig. 5d. Each beam has 3 rows of arches, the middle one assembled to the external rows by draw pegs and keys. This three rows beam, was suitable to a span between 7 and 9 meters. Those segmental arches must be made of curved timber, because the fibers of the wood, as they are also curved, are stronger and offer better resistance to the loads and do not split, as could happen if the fibers were straight. All the arch pieces must have the same dimensions and be well straightened to make the complete contact between them, and be strongly fastened by the draw pegs [9].

Modern trusses for long-span application are described by Andrea Palladio in his I Quattro Libri dell' Architecttura, first published in 1570 [10]. The good performance of the Bridge over the Cismone 

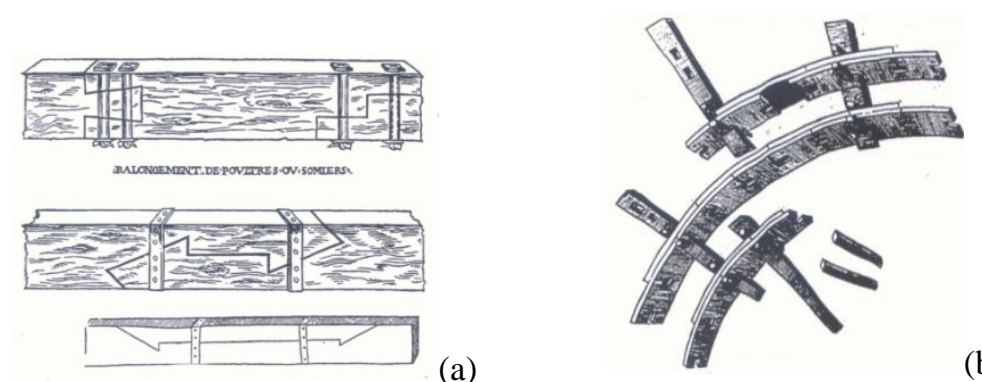

(b)
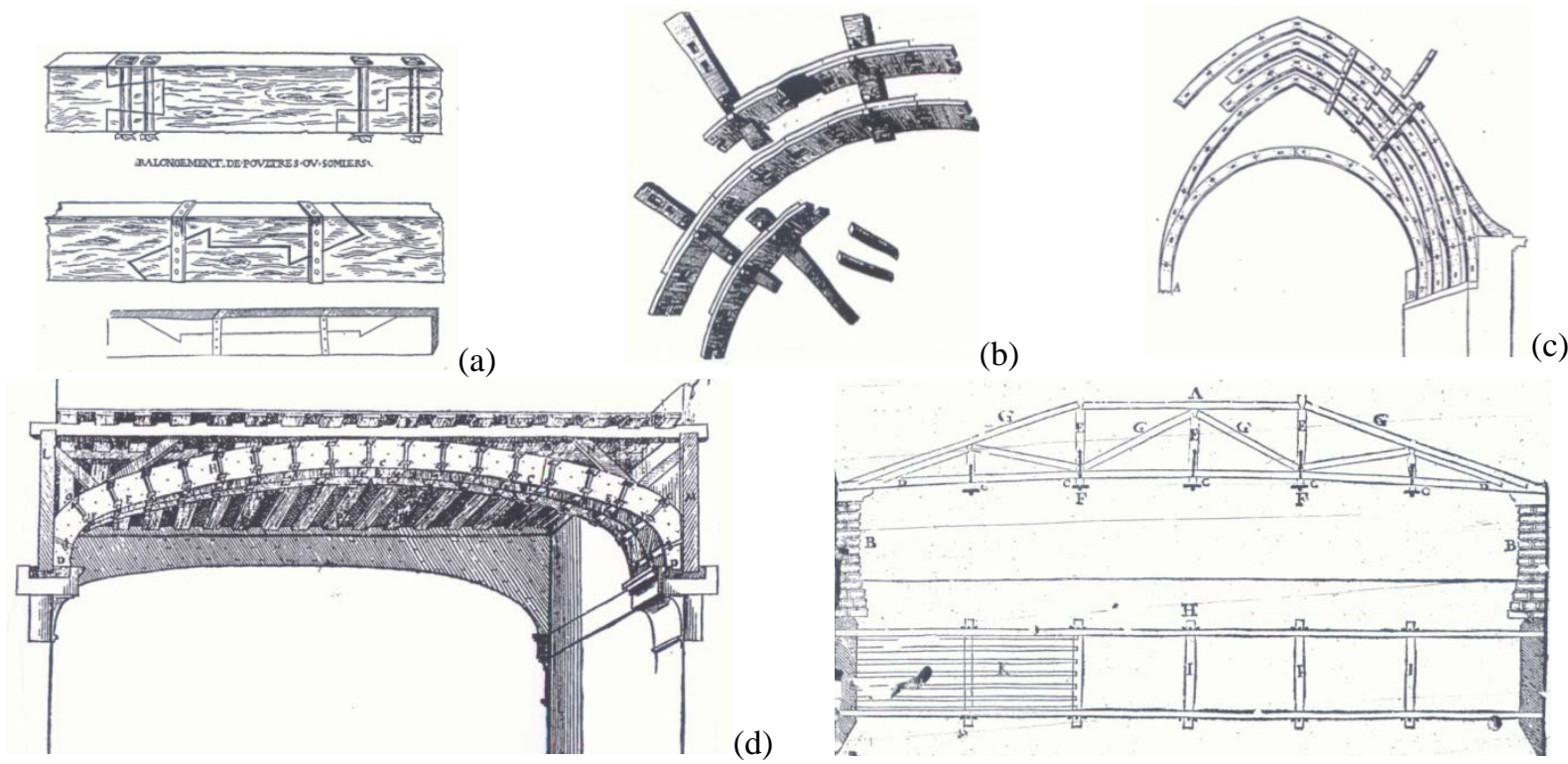

(d)

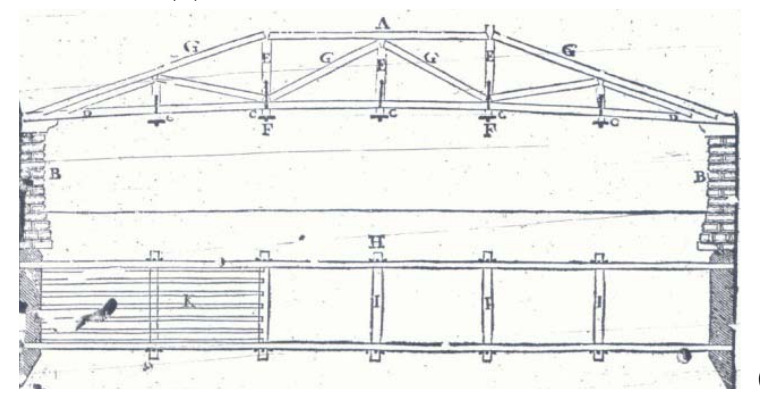

(e)

Fig. 4 (a) Way of bring together pieces of timber through steel straps to make a built-up beam, Book III, L'Architectura (De Re Aedificatoria), Leon Battista Alberti, (translated into French L'Architecture et Art de Bien Bastir, by Ian Martin,1553). (b, c) Segmented timber arch for ceiling support (Philipert de l'Orme, Vol. II, 1561); (d)Segmented timber arch for ceiling, and floor support (Philipert de l’Orme, Vol. II, 1561); (e) Bridge over Cismone River, Andrea Palladio, I Quattro Libri dell'Architettura, 1650, 3th Book, Cap. VII.

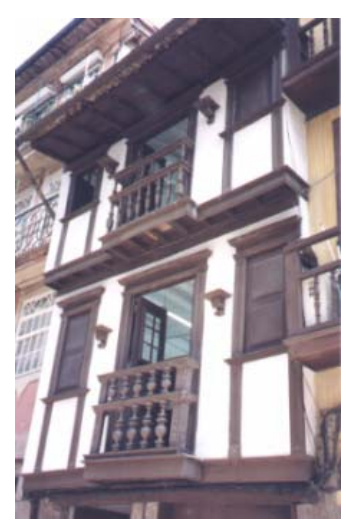

(a)

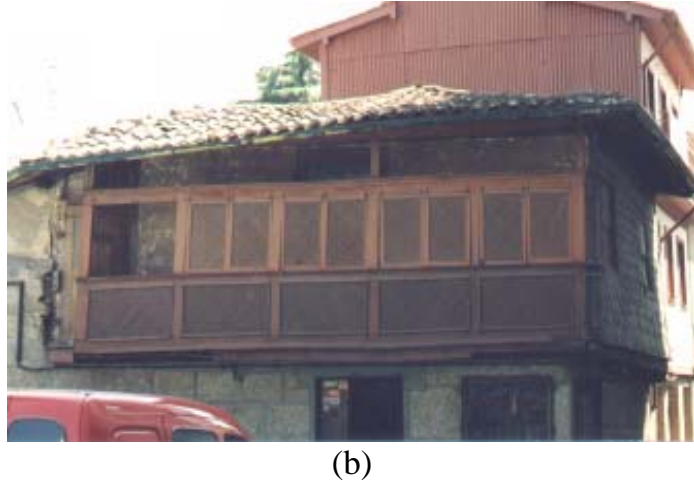

(b)

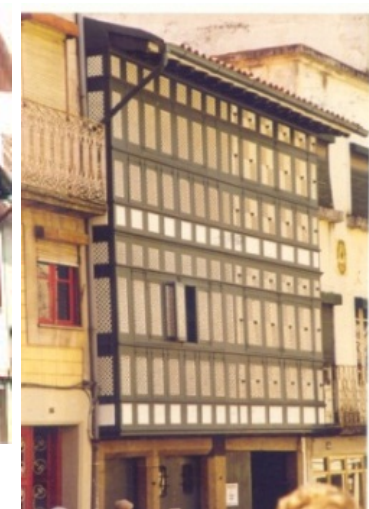

(c)

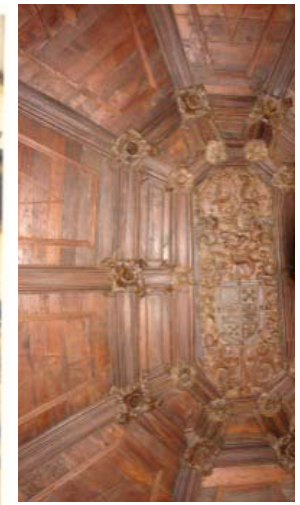

(d)

Fig. 5 (a, b) Renaissance building in Egas Moniz Street and "Casa da Rótula”, Guimarães; (c) Renaissance building, Souto Street, Braga. 1999; (d) Kneading-trough ceiling, Cidadelhe Palace, 2006.

River in northeastern Italy, results from the fact of its different partsare reciprocally supported by using bolted metal cramps to join the vertical elements to the lower chord (Fig. 4e).

The river has $30.5 \mathrm{~m}$ span under the bridge. The length of the bridge was divided in 6 equal parts and the extremes were supported by abutments. At the other 5 division points of the bridge sub-structure, were disposed cross beams, and above the latters, keeping at a certain distance to the edges, were placed other beams at full length, to serve as parapets of the bridge. Above those ones, king struts are dressed with the formers, and are assembled to the beams, through iron harpoons which pass through the extremes of the beams passing over the parapets. In that way, all the timber-framing is so well joined and connected, that the cross beams of the bridge, and those ones of the parapets, work as a single piece with the king studs which, in this way, bear the bridge cross beams, and are, also, reciprocally supported by the beams and wind braces between king 
studs. Then, the major loadings coming to the bridge, more tightened and fastened become the timber-framing, with the verticals and lower chords in tension, while all the diagonals and upper chords are in compression [10]. The lower chords of the bridge truss, single timbers spanning the entire length of the bridge, must have been used at several locations in the lower chords, some type of tension splice, possibly reinforced with iron strapping.

\subsection{Renaissance Construction in Portugal}

In Portugal, we can find renaissance construction which structural timber-framing rests above the masonry ground-floor walls, projecting itself over the street. It is the 16th centuryexample of urban buildings in the historic centers of Guimarães, andBraga. Some of those buildings have a façade with the timber-framing composed by venetian blinds called, in Portuguese language, "gelosias" or "rótulas", protecting windows. The multi-faceted kneadingtrough ceilings appeared, also, in this period. This timber-framing technics have influences from Orient, like India and Macau and from North of Africa, when Portugal began the Discoveries process and the maritime expansion, and was an important commercial and cultural emporium (Fig. 5).

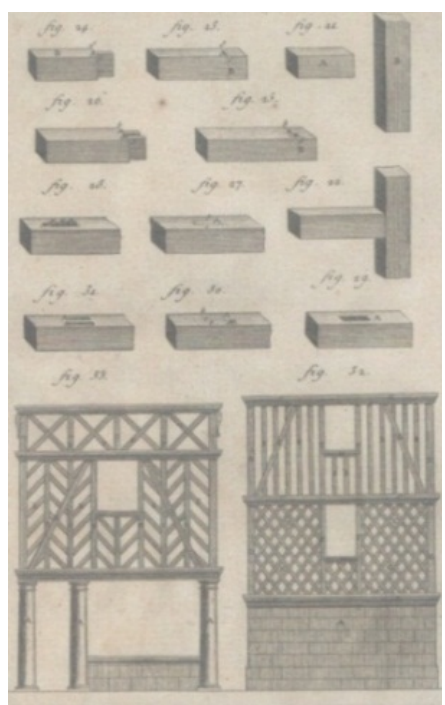

(a)

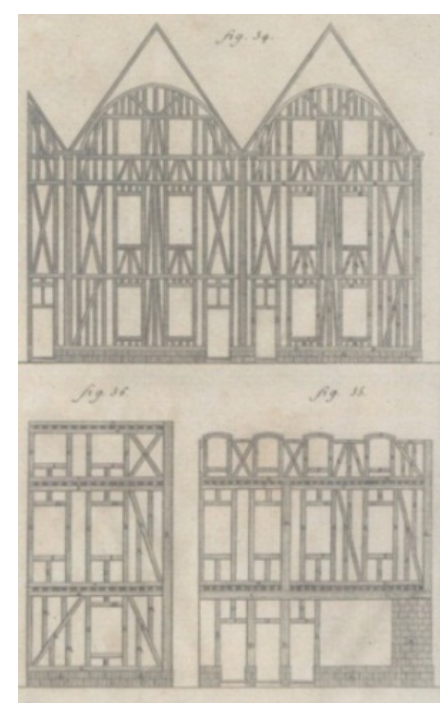

(b)

\section{17th and 18th Centuries Treatizes and the "Gaiola Pombalina”}

\subsection{7th and 18th Centuries Construction Treatises and Fortification Experience}

About structural timber-framing, we can distinguish the construction treatises of Paul le Muet, $\underline{\text { Maniére de }}$ bien batir pour toutes sorts de personnes (1681), and of J. Blondel and M. Patte, Cours d'Architecture (1777). The fortification experience and knowledge from military engineers as Sebastien Vauban, Véritable maniére de bien Fortier (1692), and Bernard Belidor, La cience des Ingénieurs dans la conduite des travaux de Fortification et d'Architecture Civil (1726), the publication of encyclopedias like that one of Diderot and D'Alembert (1751-1780) (Fig. 6), as well as preceding treatises and experience referring to structural timber-framing, were important resources for the Portuguese "gaiola pombalina" creation, the box-frame construction of Marquis of Pombal period. This last one resulted in a structural timber-framing model improved by Manuel da Maia and Carlos Mardel, especially with regard to its seismic behavior [11]. From the Portuguese fortification experience before the earthquake of 1755 , we can refer, for example, the Método Lusitânico de desenhar as fortificações das

Fig. 6 Encyclopédie, Diderot et d'Alembert: (a) «Assemblages et pans de bois anciens»; (b) «Pans de bois au moderne»; (c) «Mansardes»; (d) «Nouvelle manière de fonder les pilles». 
praças regulares e irregulares, of Luís Pimentel, 1680, influenced by Turim citadel fortification and other European ones. Pimentel, at the time, indicated how to consolidate the ground where fortified places pavements, of slabs or planks, were to be raised, for heavy artillery support. The planking esplanades were fixed on oak or elm horizontal beams, nailed to the timber-piles heads of the foundations. Those beams were spanned $1.10 \mathrm{~m}$ to $1.20 \mathrm{~m}$ and the spaces in between were filled with beaten earth or masonry and bitumen. Above the beams were fixed large planks of 4 thumbs thickness [12].

Mateus do Couto, in his treatise of 1631, recommends the Portuguese stone pine, if hewed during January's moon, striped the bark and immersed in salt water, for some time, to cure. To timber-framing, the best wood was the chestnut of Galicia, and, to wall-plates, the oak of the same region, when well dried. The hewing of those timbers must be done between spring and autumn, to get a timber of superior quality [13].

Belidor, in 1729, distinguish the oak as the most suitable wood for construction, owing to its hardness and toughness. Even inside the water, keeps those properties and in good repair for long time, as it was proved by the timber-piles foundations of Ancient Rome buildings. The oak beams keep in good repair, for 700 or 800 years, since the right precautions were taken. The oak must be hewed between 60 and 200 years old, being the most suitable age around the 100 years old, when it reaches the maximum of strength and height. The deal, or the wood of Flanders pine, was also used in the buildings, for beams and floors. The most suitable hewing period is after October till early March, when the sap is not active yet, and the pores are narrower. The hewing in the last quarter of the moon, produce a wood with less humidity inside the pores. The hewed timber must be protected in a dry and sheltered site, during 2 years, at least, before being used in construction (Belidor 1729).

\subsection{The “Gaiola Pombalina” (Pombal’s Box-Frame)}

The Lisbon earthquake of 1 November of 1755 had razed part of the town to the ground, besides tons of dead. The Marquis of Pombal, prime-minister of King D. José I, takes urgent measures to the reconstruction of Lisbon lowland (Baixa de Lisboa), imposing a urban regularization characteristic of European illuminist towns, like London, Paris, Trieste, Turin andothers, predictive of neoclassic style.It was effectuated the razing of all had left of the old towndestroyed by the earthquake, the constitution of an urban reticle between the two squares, Rossio and Terreiro do Paço, opened to the Tejo River, the enlargement of the streets and the restriction of the height of the buildings, which must constitute symmetrical façades, as they were designed by Eugénio dos Santos e Carvalho.

The richest of the 3 proposed types of building constituted a five-story-plus-attic one, and the façade have ashlar masonry socle, corner square pillars and cornice, and spans lined by ashlar masonry frames. All the renovation enterprise of Lisbon Baixa obeys to a practical and rational spirit. The urban reticle, the façade model and the prefabricated construction members and materials with standard dimensions, made viable a construction system of quick and economic implementation. The anti-seismic construction, which timber-framing have the spaces in between filled with masonry of small stones and an incombustible wall cladding, was going, on the other hand, to meet the economic, social and urban nature preoccupations of Marquis of Pombal and the urgency character and construction safety purposes of Manuel da Maia. The French, Italian, Netherlands urban and constructive experiences and theories were profited, although the Lisbon box-frame is of Carlos Mardel authorship [14]. In Lisbon, before the earthquake, were built timber tens, produced in Netherlands (where Portugal had, at that time, the "Flanders Factory”) and imported by Portugal, being mounted in 24 hours [11]. Throughout Lisbon reconstruction, after the 1755 
earthquake, in the buildings constructed according the box-frame system, the most used timbres were chest, oak, Flanders-pine and land-pine, from Leiria pine-wood, in Portugal [15].

The foundations withtimber-piles, in aquifers soils, consisted in drive in a necessary number of timber-piles for bearing the building loads, without its differential seating risk. Since has been avoided the dryness and humidity alternation in the timber-piles, those ones could last forever.The timber-piles of the Pombal's box-frame (gaiola pombalina) of Lisbon (Baixa de Lisboa) are disposed in parallel rows (2, 3 or 4), spanned $0.30 \mathrm{~m}$ to $0.40 \mathrm{~m}$. The alignment of the piles is disposed parallel to the façades rested on the timber-piles foundation. The intervals were filled with masonry stones beaten with the hammer. Above the timber piles were fixed timber railings, constituted by longitudinal pine torus, with $0.15 \mathrm{~m}$ of diameter and transversal ones, above them [15]. The timber frame must be always immersed, around $0.50 \mathrm{~m}$ beneath the lower water level. It was, then, covered with masonry, or with the pavement which could be with slabs or planks. The foundation of the pillars and masonry walls could be joined together by brick arches [16]. When the foundations reached the threshold level, or when they were raised constituting the masonry walls of the ground-floor, which bear masonry groined vaults, then, the box-frame was built.

The gaiola pombalina, Pombal's box-frame is a tridimensional connection system, with different and well-connected construction elements, characterized by certain flexibility. In case of an earthquake, the filling and cladding materials of the façades were projected from the timber-framing to the street, keeping intact the building timber-framing and safeguarding the human occupants. The story wall-frame, the floors, the roof truss, the floorboards and the ceiling boards work together as a bracing system, joining all constructions members together. The timber-framed walls (Fig. 7), with $0.20 \mathrm{~m}$ or 0.15 $\mathrm{m}$ thick, make the structure of façades and interior partition walls and work as a connection system tied to the masonry and, also, support the floor and partition timber-framed walls. The connection between timber-framed walls and masonry walls is reinforced through bolts. The connection of the floors to the transverse main walls is through metallic pieces. The connection of the timber-framed façade to the masonry which cover the former is through small wooden members called "hands" (Fig. 7a). The connection of the timber-framing to the squared stones is through metallic cramps [15].

The box-frame points where are concentrated greater stresses, was made the reinforcement of the connections between timber members through iron straps. When the façade reduced its thick from a story to the upper one, making a step in the intrados, there was insertedsolid strutting, between the two jetty beams of the floor which run between two parallel walls of support. If a plate had to cross a longer span, to prevent the bending when loads are applied, it was reinforced with a horizontal timber member, and diagonal members, the braces, a complex whole which made possible the unloading on the posts of the timber-framing. The partition wall, "frontal tecido", (Fig. 7b) was constituted by timber-framed walls similar to the former ones. Have posts and studs, connected to the superior and inferior plates, and joined together by rails and St. André braces (Leitão 1896). The lighter partition walls were thinner and could have a similar construction to the former ones. It was the case of the hanging partition wall, called "tabiquesuspenso" (Fig. 7c) in Portuguese, which does not load directly on the floor beams, and was constructed at the same time as the box-frame.

\section{Mechanics Applied to Strength of Wood in 19th Century}

Jean Rondelet, in his TraitéThéoriqueetPratique de l'Art de Bâtir, of 1810, in the carpentry chapter (Fig. 8), developed a comparative study of contemporaneous French, Russian and German construction technics. He 

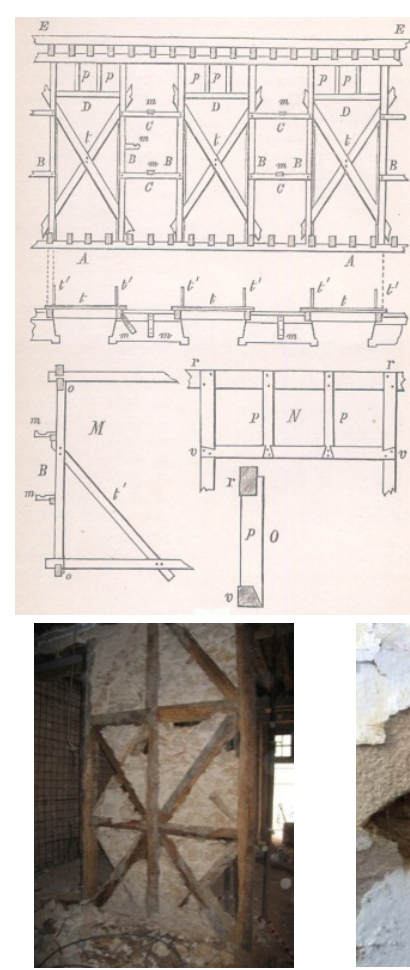

(f)

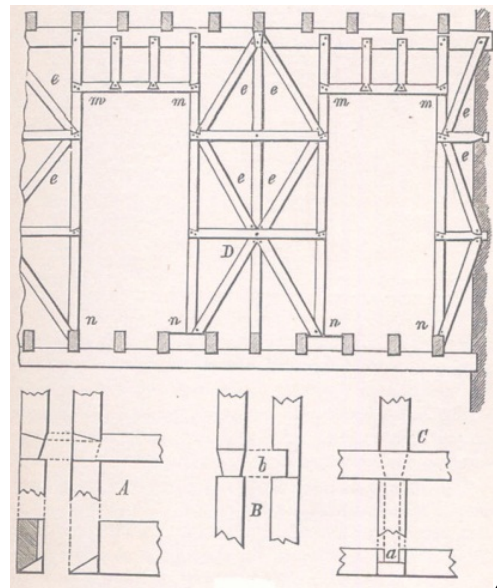

(b)

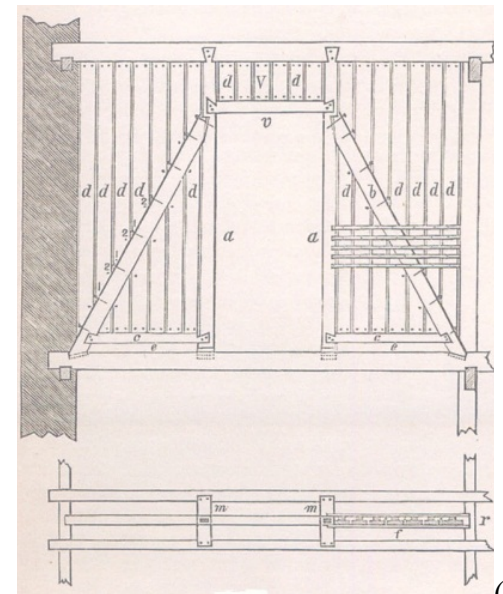

(a)

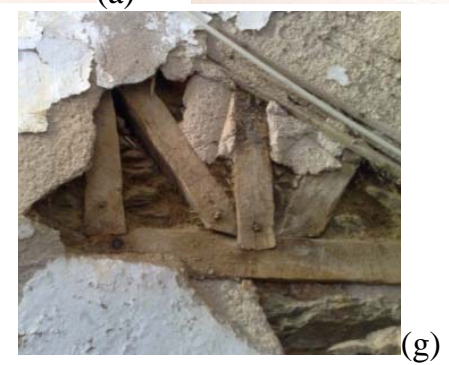

(g)
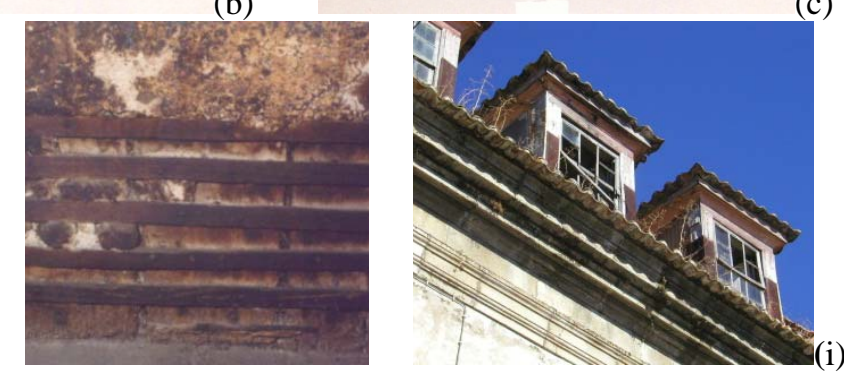

(h)

Fig. 7 “Gaiola Pombalina” [16] (a) façadeframe; (b) "frontal tecido"; (c) "tabique suspenso"; (f) partitionwall, 2006; (h) detail, Ermelo, 1999; (g, i) detailandattic, Provesende, 2008.
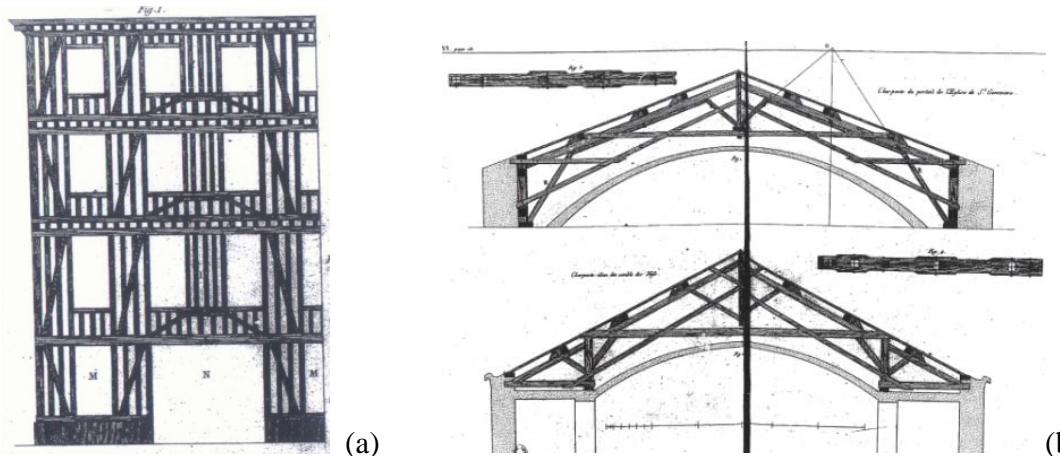

(a)

Fig. 8 (a) Timber-framed wall; (b) Carpentry of St. Geneviève Church [4].

(b)

warns that the timber-framed walls and partitions, of little thickness, are not self-sustaining walls, and for that reason, must be tied to the adjacent masonry walls and, also to the floors through metallic cramps or wrought-iron rods [4].

Paul Planat, in Pratique de la MécaniqueAppliquée a la Résistance des Matériaux, of 1887, makes some warnings in relation to connection between timber members of composite structures. With regard to cross-sectional area reduction, it was determined the magnitude of member stress, and the necessary cross-sectional area to that stress not go beyond the ultimate limit stages of timber member. It was important to take into account the reductions occasioned by the necessary notches to the joining. When a compression member runs into another member, it is executed an oblique tenon in the first one, which goes to lodge in a mortise of the receiving member, avoiding any lack of verticality; the two lateral faces complete the contact. This is the arrangement adopted by joining in a roof truss, the rafter foot on the tie beam and on the king post (hanger), 
the braces on the rafters or hangers, etc. The tenon occupies, in a general way, $1 / 3$ of the theory cross-sectional area (Fig. 9a and 9b).

The rafteris subjected not only to compression, but also to tension stresses, and the joining at its extremities, although it weakens the tension member by removal of an amount of section, do not reduce the stiffness of the joint, since in the point where a tension member rests on the extreme supports, the bending moment is null as the flexural tensile stress. The tension members, as the tie beam, require a special attention. To those kind of members, if it is not possible to resort to wrought-iron rods (Fig. 9e), then it can employ bolt connections which weakens timberslittle. The wrought-iron bolts are sustained, mainly, by adherence or friction produced by tightness. They resist to the compression force which can be accidentally produced because of the irregular force distributions under different applied loads (Fig. 9c).

With regard to shear strength, this one is important at the top side of the beam. It can be calculated, approximately, the distance from the notches which must be regarded. To the Flanders-pine, for shear with a stress component parallel to the grain, the ultimate limit value shear strength was $0.42 \mathrm{Kg} / \mathrm{mm}^{2}$. Subjected to a stress perpendicular to the grain, the Flanders-pine could reach higher values, 6 a $8 \mathrm{Kg} / \mathrm{mm}^{2}$ for shear strength, and $0.6 \mathrm{Kg}$ to $0.8 \mathrm{Kg}$ as safety load. It was known, by empirical experience, that wood resists better along the grain, to tensile stress than to shear with a stress component parallel to the grain. A Flanders-pine member is easier to split than a chest one. The tensile strength of chest, when tension is perpendicular to the grain, is about $1.60 \mathrm{~kg} / \mathrm{mm}^{2}$, and when tension is parallel to the grain is only 0.16 $\mathrm{Kg} / \mathrm{mm}^{2}$. So, a Flanders-pine B rafter applied in $a b c d$, on the A tie beam (Fig. 9d) a horizontal stress of $3 \mathrm{Kg}$, for example, and the tie beam having $0.250 \mathrm{~m}$ of width at the interested part, it must give to the $\mathrm{C}$ member a length, at least, of $30 \mathrm{~cm}$, if it is a Flanders-pine member. Is necessary, indeed, if length $f c$ is designated $l$, that $l \times 250 \times 0.042=3,000$, where is retired forlthe value $300 \mathrm{~mm}$. It will be finding $80 \mathrm{~mm}$ if itis a chest member, standing by the admitted hypothesis [17].

The designated «Coronel Emy System», according to Planat, consists in a composed structure which use boards with the greater surface turned to the intrados to create arches of rectangular cross-section (contrarily to de l'Orm arches, which timbres have the larger surface at the façade). Those boards were superposed in the way of spring leaves, forcing to curve themselves and retaining that shape through fasten straps around the section (Fig. 9f) [17].

\section{Survey and Restoration of Historical Timber Buildings}

In restoration interventions, the general principle is the one of using the same wooden specie found at the original building. When the structural timber-framing is of pine, particularity vulnerable to the depredation of insects and rottenness, the interventions have gone in the way of the substitution of deteriorated parts by more resistant species. Nowadays it is not necessary to resource to this substitution, thanks to chemical treatments improvements. In case of timber-frame constructions, which life is ending, it can be applied the following methods: dismounting and rejoining of timber members with restricted incorporation of new members; periodic reconstruction according the original model; setting the building under a shelter; construction to scale, of a model. The restoration of timber buildings begin, generally, by their complete dismounting. Each one of their members is carefully examined; those ones broken or rotted are partially or integrally substituted by new ones, inserted in the buildings. It must be carefully preserved the maximum of original members, especially those ornamental ones. A timber-framing building, through its life, loose gradually and inevitably the primitive components and original materials, but it survive, because of the substitution of the deteriorated parts, keeping its original aspect. The restoration becomes a dismounting and rejoining process (Fig. 10). 

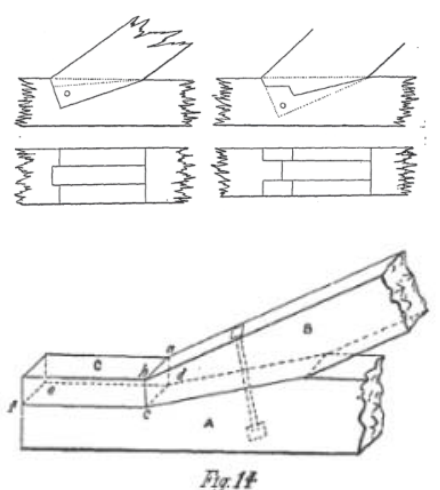

(a)

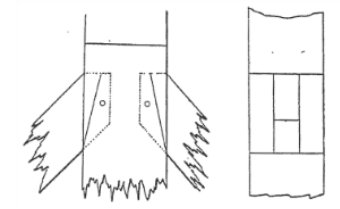

(b)

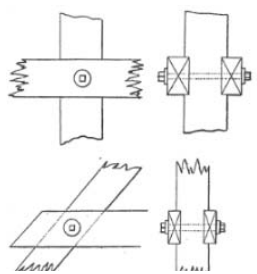

(c)
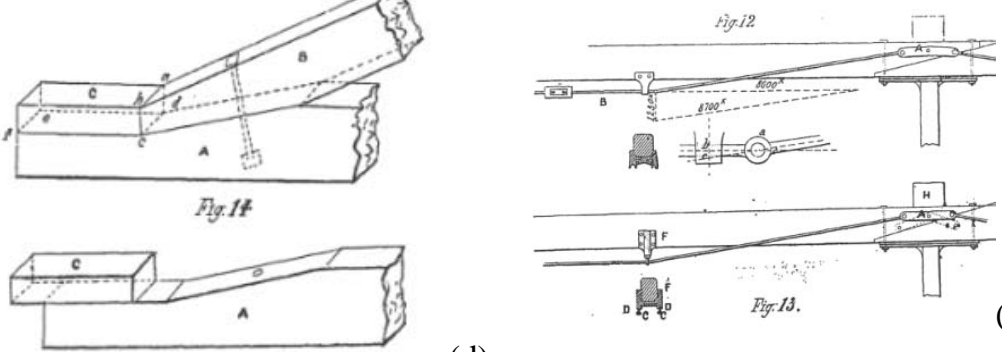

(d)

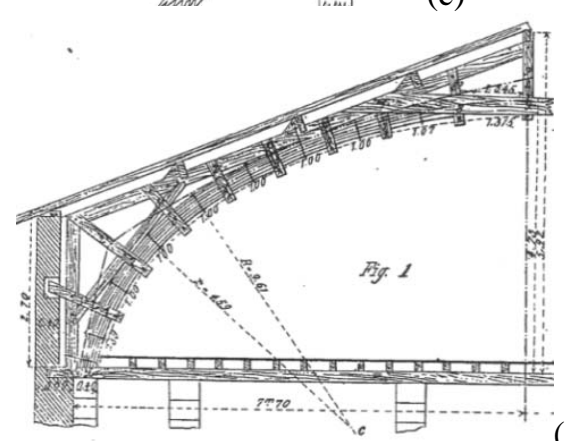

(f)

Fig. 9 (a, b, c, d) Joints; (e) wrought-iron rods; (f) «Système du Coronel Emy» [18].
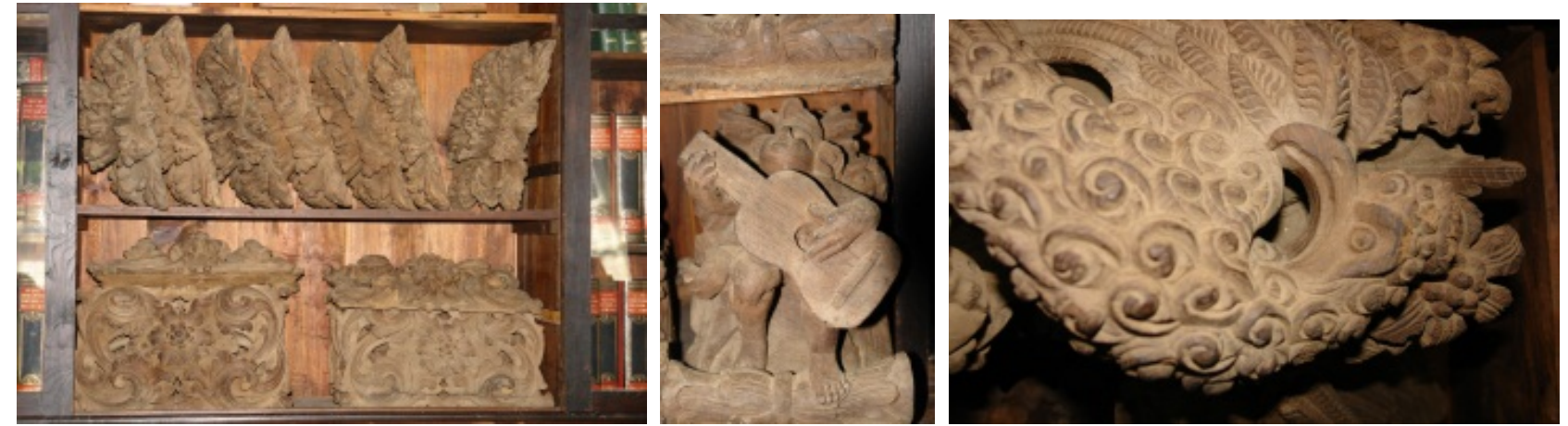

Fig. 10 Dismounted decorative members of a 17th century chest ceiling, Cidadelhe Palace, 2006.

Some timber-framed buildings are well-preserved in their original sites, because are sheltered by a more recent construction. So, it can resource to a shelter construction of wide span to keep in good repair an historic timber building. The shelter must be acclimatized, not inflammable, and resistant to earthquakes.

The construction, to scale, of amodel must be done by a master of carpentry. To reproduce conveniently all details, the maquettes must be superior to $1 / 10$ scale. In this way, the maquettes can reproduce simultaneously the construction and ornamental members, and be complemented by drawings to scale and photos. The models of decorative motives or paintings of the building, before and after its restoration are very useful [18].
Repair joints must be well distinguished in the historic structure, facilitating its behavior monitoring. Straps are preferable to bolts, because of some risk of corrosion with the latter. But a good intervention, to safe the structure for long time, is to use steel plates on either side of a fractured member bolted through to each other. In flitches, stainless steel should be resorted where a plate must be entirely bedded in the oak.

It is better to avoid glues (epoxy and polyester) and those ones must never be used in construction joints, to keep the flexibility of the frame, essential to the survival of the historic building. The use of glues in partially rotted timbers, produce moisture collects at the back of the impervious filling, and then, the timber at the interface rots. Special circumstances may justify plastic repairs, for instance, where timber members must be bedded in damp masonry or brickwork, or the 
strengthening of a plaster ceiling which beams and joists above it are rotting or decayed claim the impregnation or insertion of glass fiber reinforcement with epoxy resin molded round it [6].

\section{Conclusions}

In the course of different carpentry treatises, along the centuries, rules were enunciated for timber structure connections and were described the processes followed in the most frequent cases. In some ancient joining, to link timber members subjected to different stresses, they were nailed. It happens, however, that members subjected to stresses tend sliding, one over the other, and just only the nails offer resistance to those stresses, resulting in a not very solid joining. For that reason, the pieces to assemble are, generally, notched in such a way that supported surfaces of timber members are perpendicular to stresses which subject them.Joints correspond to the details whereby one timber piece is linked, attached or related to another. The receiving member has a mortise and support all the forces transmitted from the other member. The nails, bolts and keys employed in joints, are used to fix the relative position of linked timber members and not to support the forces transmitted from one member to another through the joints.

The details of the joints change with the shape and arrangement of the members to connect, but also with the direction of member internal forces. Is a common rule, to render possible the perfect contact between the joint surfaces to be engaged, to make the force distribution uniform as much as possible at the member joint, avoiding any excessively overloaded surfaces. Another referred prescription is that one the notches made in the joining members must be in such a way that the removal amount of section does not weaken the individual members and joint. The same must be referred for the holes to bore to introduce the keys and bolts.

With regard to the cases designed to assemble timber members in right angle with mortise and tenon joint
(Fig. 11A, 1, 9, 10, 11), at the end of one member, the tenon, is cut away to form one or two shoulders and engage, at right angles, with a mortise; the tenon must have $1 / 3$ of the cross-section thickness and the mortise depth of $2 / 3$ of height of the receiving member.The tenon is a little bit shorter then mortise and the edges must be chamfered to not hurt the bottom of the mortise. The joint can be more complexor strengthened like tusk tenonjoint used in floor construction or when two beams are horizontal and the tenon has to support significant vertical forces. In double dovetail halvedjoint (Fig. 11A, 10), is designed to improve the shear strength. The halved joint (Fig. 11A, 9, 10), is used when one member crosses another, as in the case of collar and rafter, and when have the same cross-section area and a cut extending to half the depth of one member fits into a rebate cut to half the depth of the other member. This joint is designed to resist to tension stresses.

In Fig. 11A, 8, is represented the crossing of two members through a halved joint; both members are respectively weakened but uniform surfaces on both sides are maintained. In this case the members do not make a right angle.

In the joining of members in the same vertical or horizontal arrangementwe can have different joints (Fig. 11B, 2-6); the scissor joint is a scarfed joint used vertically when a post is composed of two members. Those joints are, generally, reinforced with iron straps and the depth of the notched is the same as the width of the member. The buid-up beams (Fig. 11B, 13, 14) are composed of two pieces of timber tied together through scarfing and involve iron straps, insertion of keys and indenting adjacent surfaces, to prevent sideways sliding; bolts were used to keep them securely connected. The splayed scarf joint where the splay is in two interlocked parts and, tighten the joint with keys, bolts and straps, distributes better the forces. This is the joint which offers major resistance to tensile stress. The splayed and tabled scarf joint have the beveling of the tops of the two timber members to join with a 


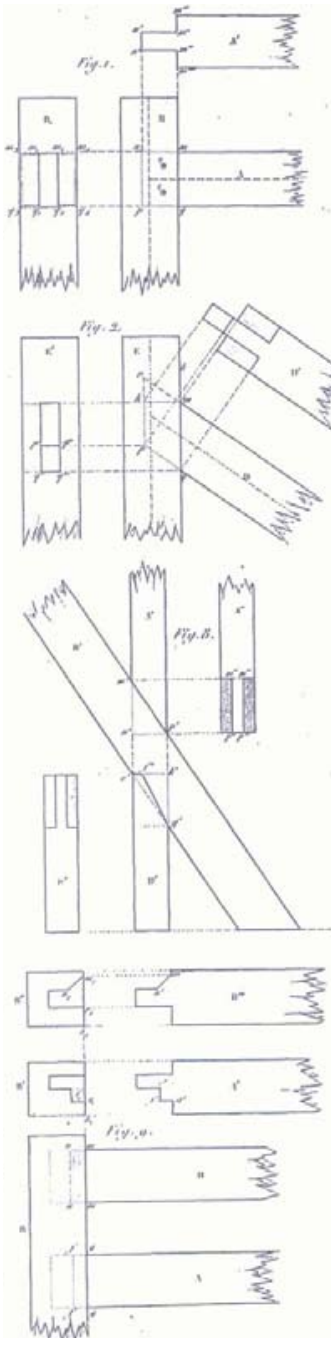

(A)
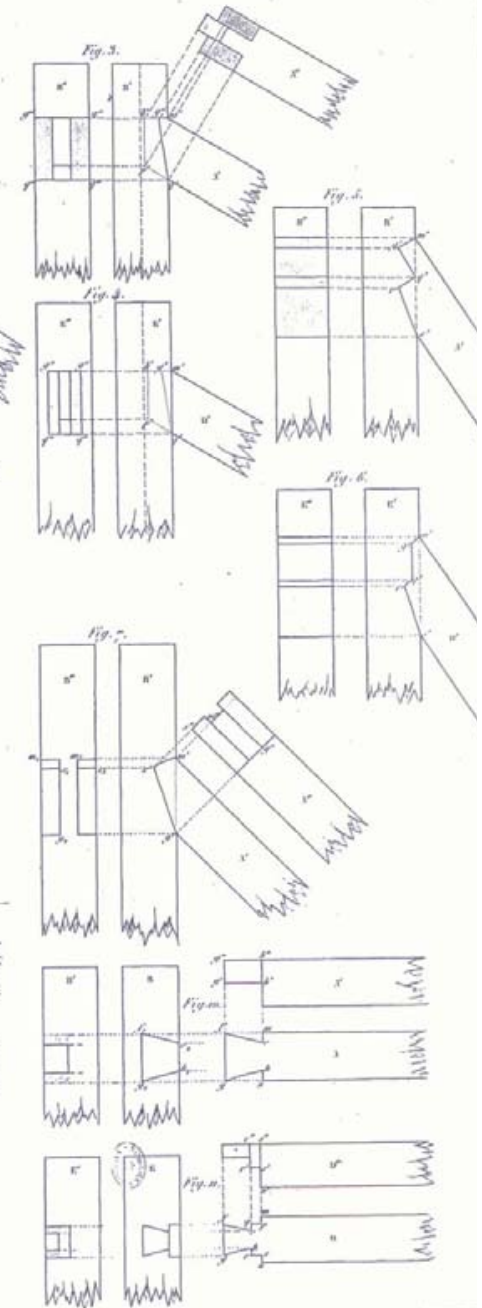
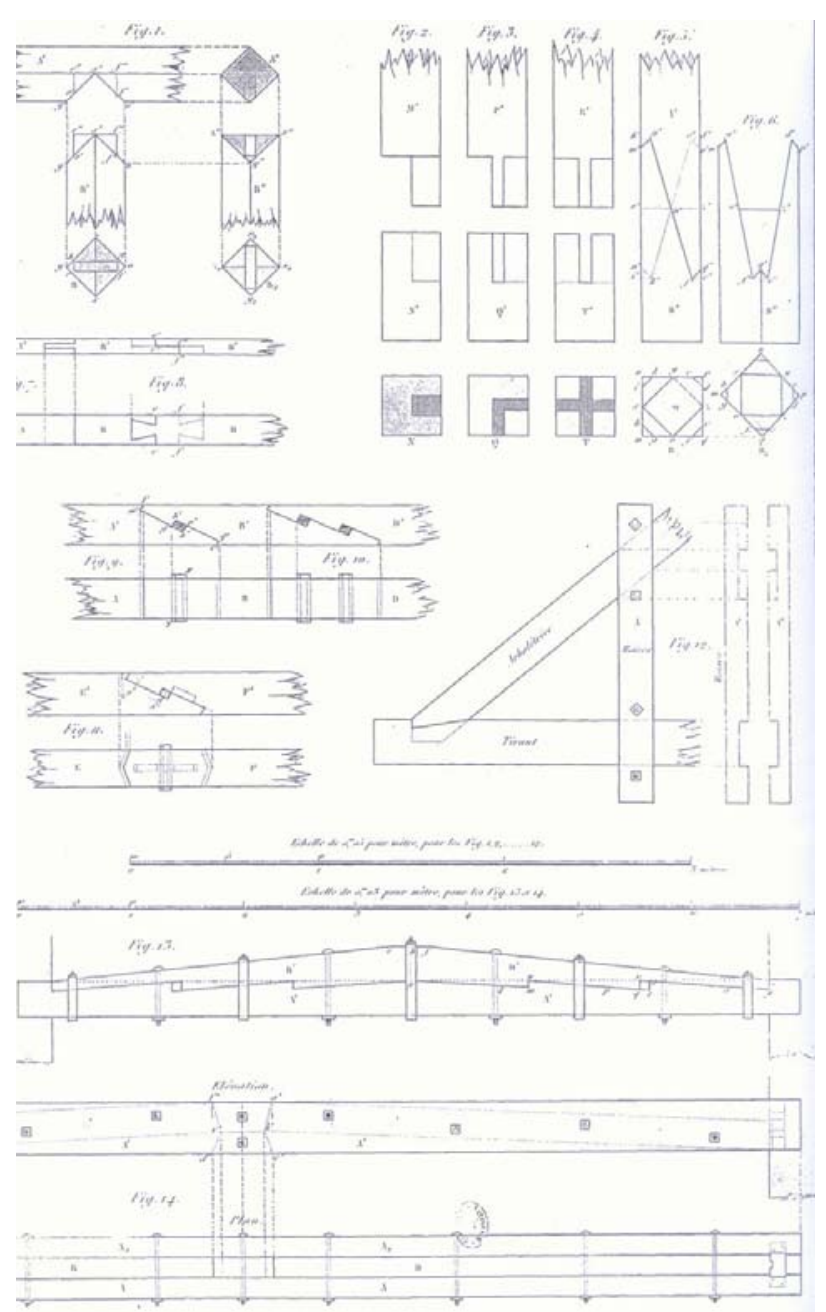

(B)

Fig. 11 Joining in framing (LEROY, C., Traité de Stéréotomie, Tomo 1, Paris, 1877). (A) 1- ortogonal mortice and tenon joint; 2 e 3- oblique tenon joint; 4 - bridle joint; 5 e 6 - bridle notched lap joint; 7 - double bridle joint; 8 - double notched halvet joint; 9 - tusk tenon; 10 - double dovetail halved joint; 11 - secret double dovetail lap joint. (B) - 1 - joining of cross beams with mortice and tenon joint; 2 to 4 - box tenon; 5 e 6 - scissors joint; 7 e 8 - longitudinal double dovetail halved joint; 9 e 10 scarf joint-splayed, tabled and keyed; 11 - scarf joint-splayed, counter-tongued, grooved and keyed; 12 - notched joints assembled; 13 e 14 - buid-up beam.

projection which prevent their disconnection when, in position, were in tension.

The woodenkeys were rods made of fibrous, hard and tough woods like oak or acacia, cutparallel to the grain, with a circular cross-section and lightly conic. The key is inserted with the caulking-mallet, conveniently tarred, in the bored hole. To be securely tightened were executed one or two notches where little wooden wedges and some oakum are forcedly introduced. The forelock bolts are wrought-iron bolts.
The heads used to be soaked in the timber member about one inch; to stop the water infiltration through the hole, this one is garnished with tow and, above the head of the bolt, is covered with a wooden stopper inserted with the hammer [19].

Philipert's arched spans in tens of meters and large vaults would create appreciable lateral thrust on a supporting wall, so this system was not practical for use in tall buildings. The arches of Emy have the inconvenient of, in consequence of the relaxation of 
tighten metallic pieces which keep the shape of structural members, suffering pronounced deformation, with the time [20].

Finally, while the original structural joints allow slight movement in the total frame without exerting stress in the members, avoiding their fracture, and keeping the knots in good conditions, the repair joints are rigid. So, glues must be avoided and plating and bolting be introduced.

Those countries whose cultural heritage comprise a significant number of timber frame buildings must adopt certain criterions, taking into account factors like durability, biologic agents, fire, humidity and climatic conditions, to assert the preservation and restoration of those buildings.

\section{References}

[1] L. T. Courtenay, Timber roofs and spires, in: Robert Mark (Ed.), Architectural Technology up to the Scientific Revolution-the Art and Structure of Large-Scale Buildings, The MIT Press, London, England, 1995, pp. 184, 188-189, 199-205, 214-215, 225.

[2] M. J. Maciel, Vitrúvio-Tratado de Arquitectura. Tradução do latim, ISTPress, Instituto Superior Técnico, Lisboa, 2006, Livro II, Cap. X, p. 90; Livro VII, Cap. III, pp. 269, 270.

[3] J. P. Adam, La Construction Romaine - Matériaux et Techniques (2nd ed.), Grand Manuels Picard, Paris, 1984, pp. 132-135.

[4] J. Rondelet, Traité Théorique et Pratique de l'Art de Bâtir, 1ere Partie, «Charpente», Paris; 1805-1810, Tomme 3, pp. 116-119; Tomme $4^{\circ}$, pp. 125-131.

[5] J. Chapelot and R. Fossier, Le Village et la Maison aux Moyen Age. Collection Bibliothèque d'Archéologie, Ed. Hachette Littérature, Paris, 1985, pp. 260-264, 267-272, 293-304.

[6] F. W. B. Charles, Conservation of Timber Buildings, Donhead Publishing Lda, Great Britain, 2003, pp. 48-50, 120-127.

[7] R. W. Brunskill, Traditional Buildings of Britain-An Introduction do Vernacular Architecture, Victor Gollancz Ltd, London, 1985, pp. 76-77, 81-82.
[8] M. Viollet-le-Duc, Dictionnaire Raisonné de l'Architecture Française du XIe au XVIe siècle. B. Bance Editeur, Paris, tome 1 (Maison), 1859, pp. 220-221, 251-258, tome 6 (Pan de Bois), pp. 37-44.

[9] P. de l'Orme, Nouvelles Inventionspour Bien Bastir et a Petits Fraiz, Paris, Vol. II, 1561, pp. 11-44.

[10] A. Palladio, I Quattro Libri dell'Architettura (3th Book), translated into French, Paris, 1650, Cap. VII, 1642, pp. 161-162.

[11] J. A. França, A Reconstrução de Lisboa e a Arquitectura Pombalina, Vol. 12, Instituto da Cultura Portuguesa, Secretaria de Estado da Investigação Científica, M.E.I.C., Amadora, 1978, pp. 9-41, 56.

[12] L. S. Pimentel, Método Lusitânico de Desenhar as Fortificações das Praças Regulares e Irregulares.Publicação da Direcção do Serviço de Fortificações e Obras do Exército (2nd ed.), Lisboa, 1993, pp. 124-135.

[13] M. Couto, Tractado de architectura que Leo o Mestre, e Arquitecto Mattheus do Couto, o Velho, no Anno de 1631, Manuscrito, Biblioteca Nacional de Portugal, Lisboa, 1631, p. 59.

[14] L. Benevolo, Historia de la Arquitectura del Renacimiento - La Arquitectura Clásica (del siglo XV al siglo XVIII), trad.Maria Teresa Weyler, Editorial Gustavo Gili, SA, Barcelona, Vol. 2, 1988, pp. 1324-1339.

[15] V. Cóias, Reabilitação Estrutural de Edifícios Antigos Alvenaria, Madeira - Técnicas Pouco Intrusivas, Argumentum, GECoRPA, Lisboa, 2007, pp. 7-77, 79.

[16] L. A. Leitão, Arma de Engenharia - Curso Elementar de Construções Elaborado segundo o Programa da Escola Central da mesma Arma, Imprensa Nacional, Lisboa, 1896, pp. 211-213, 292-298.

[17] P. Planat, Pratique de laMécaniqueAppliquée à laRésistancedesMatériaux (5th ed.), Paris, 1887, pp. 533538, 684-691.

[18] M. Sckino, La préservation et la restauration des monuments de bois au Japon, La conservation et la restauration des monuments et des bâtimentshistoriques, UNESCO, Paris, 1973, pp. 223-227.

[19] R. C. Ferreira, A Construção do Navio de Madeira, Lisboa, 1932, pp. 15-23, 27-30.

[20] T. J. E. Mateus, Bases para o dimensionamento de estruturas de madeira, Memória $n^{\circ} 179$, LNEC, Lisboa, 1961, pp. 12-21. 